\title{
Role of the Construction Market and the Firm for Sustainable Development and Sustainable Construction
}

\author{
Aneta Marichova
}

\begin{abstract}
Sustainable development and sustainable construction present every firm with new challenges. The concept of sustainability is the new driving force for the firm and decision making, which are part of the overall sustainable strategy. The implementation of this strategy is a factor for creating, offering and realizing additional economic, social and environmental value for the client, stakeholders and society as a whole, and building competitive advantages. Detailed knowledge of the principles and requirements for sustainability and the necessary changes at the market and company level are mandatory for every construction manager. The main goal of the research is 1) analysis of the role of the construction market and the firm for sustainable development and sustainable construction, 2) outlining the necessary changes in the organization and management of the firm in order to create sustainable construction firm and development sustainable construction.
\end{abstract}

Keywords - construction firm, construction market, sustainable construction, sustainable construction firm

\section{INTRODUCTION}

A general trend in the development of modern economies is the growing role of the market in the allocation and use of scarce resources. This practically means that this process is carried out by private individuals, firms, which in their behavior are guided mainly by their personal interest and the realization of higher profits. The concept of sustainable development and sustainable construction puts every company in front of new challenges and new economic, social, ethical and environmental problems [1].

The challenge of sustainable development of the construction firm is a function in the first place of the growing scarcity of resources. In the 50s and 60s of the 20th century, corporate development was mainly associated with the realization of a higher profit function of higher economic growth and higher employment, through financial assistance; investment and technology transfer to construction, because the industry is an important factor in dynamizing the whole economy. The rapid development of economies and the construction market in the last century, marked as the century of new discoveries, the application of composite materials and information technology, along with its positive results at the end of the century raises public concerns about climate change and the need to protect the environment. 


\section{sciendo}

42 Ovidius University Annals Series: Civil Engineering, Year 22, 2020

For a long time, the social role of the firm is practically limited to creating employment, paying taxes and complying with the law. Today, society's expectations have changed significantly. In the conditions of globalization and information, the control over the activity and behavior of the companies increases, the requirements of the society for social protection, active research, innovation activity, participation in the management.

Every firm develops successfully on the basis of the people it works with and the relationships between them. At the same time, they are an important factor for their development not only as professionals but also as individuals. The activity of the firm must create equal conditions for development, to improve the working and living conditions of the people. The ability to build trust in the relationship with internal and external stakeholders is especially important.

In today's dynamic conditions, synchronization and coordination of actions and interests between business, people (consumers) and society is increasingly necessary, which can be achieved by applying and developing the principles of sustainability. In this sense, sustainable development unites the main goals of society: achieving economic development, ensuring an increase in living standards (comfort) and protection, improvement of the environment (care for the future).

The concept of sustainability is the new driving force for the firm and decision making, which are part of the overall sustainable strategy. The implementation of this strategy is a factor for creating, offering and realizing additional economic, social and environmental value for the client, stakeholders and society as a whole, and building competitive advantages. Detailed knowledge of the principles and requirements for sustainability and the necessary changes at the market and company level are mandatory for every construction manager. The main goal of the research is: 1) analysis of the role of the construction market and a firm for sustainable development and sustainable construction, 2) outlining the necessary changes in the organization and management of the firm in order to create sustainable construction firm and development sustainable construction.

\section{ANALYSIS OF THE ROLE OF THE CONSTRUCTION MARKET AND THE FIRM FOR SUSTAINABLE DEVELOPMENT AND SUSTAINABLE CONSTRUCTION}

The construction market is often defined as inefficient, as participants tend to work in the short term, find it difficult to perceive innovations and are limited in rational use of the accumulated knowledge and experience in their practice. In addition, it is characterized by a low level of inter-firm relationships, which means that the same team rarely works together on more than one project and in practice leads to fragmentation of responsibility and complicates the implementation of projects and objects that meet the requirements of sustainable construction. This is a vicious circle in which construction firms claim that they can build sustainably if customers want, customers want sustainable construction if it meets their desires and provides the desired return on investment, designers are willing to design sustainably if investors are willing to pay, and investors are willing to pay if there is a demand for sustainable construction [2].

The problems are especially visible in the inefficiently built vertical connections and relations between the participating firms. Each project includes companies that come together temporarily, only to implement the project and specific goals. At the same time, these firms are likely to be involved in other projects in which they coordinate their actions and share resources with other companies involved in the supply chain. Each construction 
firm implements several different, individual projects simultaneously within its broadly defined mission and vision for development, which requires coordination of its actions with many other companies that are outside the scope of each project. The creation of a sustainable construction company requires that this practice be stopped and that effective vertical links be established through the market. This suggests that in the construction market needs to improve the level of communication and the development of partnerships, between the participating construction companies (contractors and subcontractors), architects, designers, investors, customers, managers, whether formally through agreements or simply achieved through informal relationships that allow the building of multidisciplinary teams. From this point of view, the author formulates the first hypothesis for research: The creation of an integrated management chain - a major factor in creating a sustainable construction firm.

The specifics of the construction product and the problem of environmental pollution impose in recent years the concept of life cycle of the construction product and the need for sustainable management and evaluation of the life cycle of the construction product. Construction product life cycle sustainable management is an objective process aimed at assessing environmental aspects, identifying and quantifying the necessary raw materials, production, transportation, use, reuse, recycling and treatment of waste at all stages of the product life cycle (Table 1.).

Table 1. Sustainable management and evaluation of the life cycle of the construction product

\begin{tabular}{|c|c|c|c|c|}
\hline Stage 1 & Stage 2 & Stage 3 & Stage 4 & Stage 5 \\
\hline $\begin{array}{l}\text { Required } \\
\text { resources }\end{array}$ & $\begin{array}{l}\text { Evaluation of } \\
\text { incoming } \\
\text { resources }\end{array}$ & $\begin{array}{l}\text { Project and } \\
\text { investment } \\
\text { evaluation }\end{array}$ & $\begin{array}{c}\text { Evaluation of } \\
\text { the results of the } \\
\text { construction } \\
\text { process } \\
\end{array}$ & $\begin{array}{c}\text { Evaluation } \\
\text { of the final } \\
\text { result }\end{array}$ \\
\hline $\begin{array}{l}\text { Energy } \\
\text { resources } \\
\text { and fuels }\end{array}$ & $\begin{array}{l}\text { Production } \\
\text { and costs for } \\
\text { fuels and } \\
\text { electricity }\end{array}$ & $\begin{array}{l}\text { Production and } \\
\text { delivery } \\
\text { construction raw } \\
\text { materials }\end{array}$ & $\begin{array}{c}\text { Waste } \\
\text { management }\end{array}$ & $\begin{array}{c}\text { Harmful } \\
\text { emissions } \\
\text { into the air }\end{array}$ \\
\hline $\begin{array}{l}\text { Water } \\
\text { resources }\end{array}$ & $\begin{array}{l}\text { Production } \\
\text { and water } \\
\text { costs }\end{array}$ & $\begin{array}{l}\text { Design and } \\
\text { organization of the } \\
\text { construction } \\
\text { process }\end{array}$ & $\begin{array}{l}\text { Estimation of the } \\
\text { degree of wear } \\
\text { over time. }\end{array}$ & $\begin{array}{l}\text { Harmful } \\
\text { emissions } \\
\text { into the } \\
\text { water }\end{array}$ \\
\hline $\begin{array}{c}\text { Construction } \\
\text { raw } \\
\text { materials }\end{array}$ & $\begin{array}{c}\text { Production } \\
\text { and costs of } \\
\text { construction } \\
\text { raw materials }\end{array}$ & $\begin{array}{l}\text { Construction and } \\
\text { finishing works }\end{array}$ & $\begin{array}{l}\text { Assessment of the } \\
\text { degree of } \\
\text { pollution }\end{array}$ & $\begin{array}{l}\text { Harmful } \\
\text { emissions } \\
\text { into the soil }\end{array}$ \\
\hline \multirow[t]{2}{*}{ Land } & Land costs & $\begin{array}{c}\text { Use and } \\
\text { maintenance }\end{array}$ & Recycling, reuse & \\
\hline & & $\begin{array}{c}\text { Demolition of the } \\
\text { object }\end{array}$ & & \\
\hline
\end{tabular}

Sustainable development and sustainable construction requires a radical change in the strategic behavior, organization and management of the construction firm at every stage of the construction process and throughout the life cycle of the construction product (design, construction, operation, maintenance, demolition, waste use, recycling, reuse). Life cycle 
sustainable management of the construction product integrates strategies, policies and solutions that are a function of sustainable production and consumption policy (integrated management chain) and aims to minimize the environmental and socio-economic burdens associated with the product created and its use. This process is carried out through a system for collecting, structuring and disseminating information from the various programs, concepts and tools for product evaluation throughout the life cycle. The main mechanisms for this are continuous product improvements, development of integrated product policies, process/product innovations, applying the principles of sustainable construction. The author formulates the second hypothesis: Life cycle sustainable management of the construction product - a factor for creating a sustainable construction firm.

The success of the firm today is based mainly on monitoring, assessing the dynamics of the external environment, absorption, assimilation of information, development of intangible assets, and central to them is the ability to learning and generate new knowledge. The process of learning, dissemination, integration of internal and external knowledge is a factor for success not only of the firm, but also of companies related to it. New knowledge allows the development of new thinking, which combined with experience and routine procedures, increases efficiency by discovering new sources of resources, developing relationships with suppliers, specialization and cooperation, flexibility in the vertical chain of value creation [3]. On this basis, the author formulates the third hypothesis: Building effective relationships with stakeholders (source of valuable information) has a positive impact on the creation of a sustainable construction firm.

Sustainable construction requires the development and implementation of a new business model that includes new processes of management and organization of production, which stimulate and support the process of development and implementation of new technologies and new products. In the new dynamic conditions the successful development of the construction company requires significant changes in its organization and management. This determines the fourth hypothesis for research: Organizational changes are an important factor for the creation of a sustainable construction firm (Fig. 1).

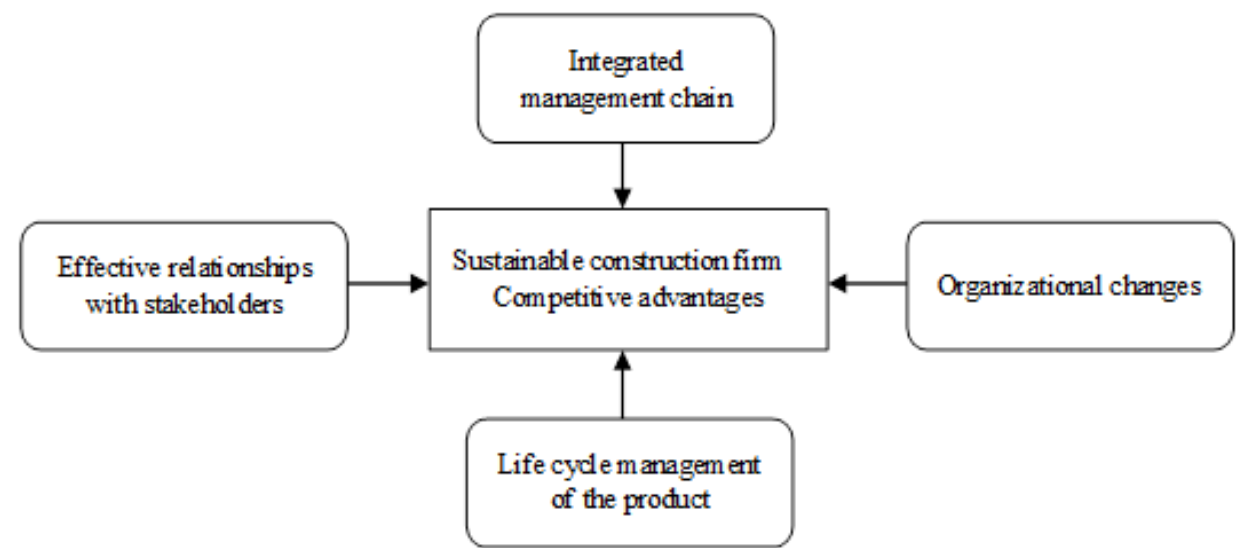

Fig.1. Factors influencing the building of a sustainable construction firm and competitive advantages 


\section{EMPIRICAL STUDY OF THE ROLE OF THE CONSTRUCTION MARKET AND THE FIRM FOR SUSTAINABLE DEVELOPMENT AND SUSTAINABLE CONSTRUCTION}

\subsection{Method and restrictive conditions of the study}

The empirical research was conducted through a developed and applied methodology for evaluating the defined hypotheses. The aim is to assess the impact of factors on building a sustainable construction firm and competitive advantages. The companies included in the study work on different segments of the construction market (civil engineering market and building construction market) in Bulgaria and have different specialization, different history, different territorial location, and different business model. An equal number of small, medium and large construction companies with different resources and competencies related to production, organization and management, different market positioning and different opportunities for sustainable development were studied. The information was collected and processed by workshops, shared opinions, evaluations, experience of managers, employees in the surveyed firms, publications and analyzes in specialized publications. A survey was conducted among managers, which includes questions related to the opportunities for creating a sustainable construction firm and the problems they face. The questions are constructed as wordings to which the respondents refer, noting their answers from 1 to 5 on the Likert scale. One part of the questions is related to the problems of sustainable construction (access to information, knowledge, standards, norms, practices, learning opportunities, etc.) and another part to the specific actions that the company believes it needs to take in order to answer the challenge. This allows the relevant conclusions to be drawn by outlining the role of the market and the firm for sustainable development.

\subsection{Main results of the research}

The processing and analysis of the results fully confirm the first hypothesis: The creation of an integrated management chain - a major factor in creating a sustainable construction firm and allows to draw the following conclusions:

According to the surveyed managers, one of the main obstacles that must be overcome in order to make sustainable construction a reality is the break with the traditional approach of relationships in the vertical chain of connections and relationships and implementing a policy of creating an integrated management chain (based of competition) that covers the entire construction process (from the production and supply of materials, equipment, design, production of the next product, the creation of the final product and its sale to the end user, demolition of the object, recycling and reuse).

The integrated management chain includes investors (clients), construction firm contractor and subcontractors, end customers, supplier companies, related organizations and activities. They participate from the beginning to the end of the construction process by building connections - up and down and creating value in the form of product and services for the end user. Thus, the scope of the chain management covers the production and supply of materials, the production of the final product, its sale to the end user, its use and waste management, generation in its life cycle. Each participant in this chain depends on the other participant and active cooperation is needed in order to achieve higher efficiency, which is achieved through long-term contracts, long-term relationships, continuity of joint work and exchange of information [4]. 


\section{sciendo}

46 Ovidius University Annals Series: Civil Engineering, Year 22, 2020

The firms in the integrated vertical management chain exchange information and coordinate within the created chain, which provides maximum benefit for all participants in it. In addition, accurate estimates for the execution of transactions and for the evaluation of the efficiency of the chain are determined. The end results are improvement in customer service, reduction of inventories throughout the chain, offering a better product, building competitive advantages for the participating firms and achieving higher profits throughout the product life cycle. The integrated management chain presupposes competition with the other chains and not between the individual companies, which allows higher efficiency of logistics through planning, organization, coordination and control over the fulfillment of the obligations of each of the participating companies. The basis for this are the constant connections, relations and exchange of information between the participating parties - the construction firm-buyer and the firm-seller (contractor, subcontractor or supplier of construction materials)

Achieved higher efficiency is a function of creating long-term partnerships between all participating firms based on common interest and good personal relationships. These relationships mean solving problems together, sharing information and risk. The requirements of sustainable construction require the active participation of suppliers of construction materials in the entire process of design and implementation of the site from start to finish together with the construction firm. The basis for effective cooperation in the integrated management chain is trust. Effective links between all participants combined with effective management of the supply chain of construction materials, and other good practices of customer relationship management ensures higher market competitiveness and allows the creation of high quality, differentiated product with specific characteristics desired by customers, reduction of production costs and price.

Building and effectively managing an integrated chain based on competition is an important factor in stimulating innovation, reducing the asymmetry of information and transaction costs, increasing specialization, developing technologies inside and outside the company and their application in creating of a sustainable construction product.

The integrated management chain facilitates the implementation of the integration and cooperation strategy and the development of complementary innovations [5]. Complementary innovations are the result of a chain reaction caused by the emergence of an innovation and the existence and development of complementary, specific assets in different activities or different firms, where each such specific asset is the result of another such specific asset and cannot independently fulfill its purpose. The strategy of integration and cooperation allows a firm to specialize its assets and use them more efficiently through a new combination with other specialized assets from other companies, which is a factor for achieving economies of scale and offering an integrated solution for customers. The interdependence of specific assets implies the creation of a package of complementary products (goods and/or services) that increase the satisfaction of the end customer. The ability of managers to identify, develop and use their specific assets in combination with other specific assets of other firms involved in the vertical chain of management is unique and often very difficult to implement.

The second hypothesis: Life cycle sustainable management of the construction product - a factor for creating a sustainable construction firm, is fully confirmed by construction managers.

The final construction product is a complex system of various elements, components, details with strong functional dependence. Standard construction practices, guided by shortterm economic goals, often show little concern for the economic, social or environmental impact of the built-up area. Sustainable construction seeks to end these practices by 
integrating a wide range of design, construction, operational and maintenance practices to ensure a healthier life, a better working atmosphere and reduce environmental impact. Therefore, according to the surveyed managers, it is especially important to apply the Building Information Modelling (BIM) and an integrated design principle in their work. This is an approach in which key entrepreneurs, professional designers, architects, landscape architects, surveyors, constructors, civil engineers work together from the beginning to the end of the construction process. In the traditional design approach, in the initial phase the possibility to evaluate a building as a whole is very small. The uncoordinated work of different designers leads to constant repairs and sometimes the necessary changes are noticed too late, only when the construction itself starts and their removal can be much more expensive. Therefore, sustainability in construction starts from the earliest stages of the project and requires the responsible involvement of all participants in the process. This allows in practice to implement a circular process in construction (sustainable consumption and production), which includes all stages of the product life cycle: raw materials, resources $\rightarrow$ product design $\rightarrow$ production $\rightarrow$ consumption, reuse $\rightarrow$ waste management and recycling $\rightarrow$ creation of new raw materials and resources for other productions [6].

The first step in sustainable managing the life cycle of a construction product is for the investor to assess how high a rating he wants to achieve, i.e. in which category wants the building to be. Higher requirements make construction and the building more expensive, but reduce long-term operating costs and the negative impact on the environment. The next step is to contact a licensed auditor. It is desirable for him to be a participant in the construction process from the very beginning to advise the investor and the designers how to optimize the building with the lowest additional costs. Upon completion of the design process, the auditor prepares a report, which is submitted for the formation of an interim evaluation by the Institute for Sustainable Development. The criteria for evaluation and certification of the building (according to the LEED standard) are nine - management, transport, energy, water, land and ecology, materials, health and tone, waste products, pollution. Each of them is evaluated according to certain criteria, which carry respective credit points, from which the overall evaluation is determined in percentages (of $100 \%$ ). The grade can be average (over 30\%), good (over $45 \%$ ), very good (over 55\%), excellent (over 70\%) and exceptional (over 85\%). It is revised after the final completion of construction and before the commissioning of the building, through on-site inspection and conformity assessment. Only then is the final assessment determined and the final certificate of the construction object.

In the ecological assessment of the impact of construction on the environment, the assessment of the construction materials produced and used by the companies occupies a particularly important place, because the characteristics of the final construction product are a function of them. According to the managers, this is a significant problem because a large part of the construction materials used today cannot be classified as meeting the requirements of sustainable construction and development. Building materials that provide sustainable construction are characterized by low energy costs for production, durability and insignificant costs for their maintenance. In addition, they must contain a relatively large amount of recycled materials, and they themselves must be produced in an environmentally friendly way, allowing them to be fully recycled and reused. This is an important factor for creating a circular economy and respectively circular construction: design and construction of buildings and facilities in which resources and materials are invested, with a high relative share of recycled ones, the source of which is the waste generated in the process of operation of the created construction sites. 


\section{sciendo}

48 Ovidius University Annals Series: Civil Engineering, Year 22, 2020

The study of the third hypothesis: Building effective relationships with stakeholders has a positive impact on the creation of a sustainable construction firm, allows us to draw the following conclusions:

There is a need for constant active communication with stakeholders - investors, end customers, shareholders, suppliers of equipment and raw materials through a constant flow of information about the firm's activities and the application of the principles of sustainability. Of particular importance is the development and maintenance of close links with research institutes and universities, which facilitate access to highly qualified personnel and information on market innovations. This is a key factor in stimulating initiative, innovative thinking, which can ensure the active participation of everyone and the implementation of any valuable idea in the direction of sustainability.

The construction firm should not be a passive, but above all an active economic entity that informs, directs consumers and changes their tastes and preferences. The main aspect of sustainable construction is the formation of long-term thinking and evaluation of consumer decisions. It takes a lot of time and effort to convince the end user (especially in the housing market) that it is more profitable, cost-effective to make higher long-term, investment costs today, against significantly lower, current maintenance costs and operation. This means a complete change in consumer behavior: from short-term thinking and planning to long-term thinking and decision-making, which can only be achieved through active communication and quick feedback.

The goal of any responsible firm should be communication with stakeholders, training and development of innovative and environmental thinking in the organization and management of the entire construction process, based on legislative and regulatory measures creating sustainability of new construction, as well as renovation of old construction in accordance with sustainability requirements. These actions give not only an ecological positive effect, but also an economic and social effect by saving energy and resources for consumption in the process of operation of buildings and facilities.

The testing of the fourth hypothesis: Organizational changes are an important factor for the creation of a sustainable construction firm, allows to draw the following conclusions:

Organizational changes should be aimed at creating a decentralized company structure and development of specialization. In the conditions of constant changes in the environment in which they work, the exit from the accepted schemes and models of behavior would allow the managers to be able to find a new interpretation of the ongoing processes, events, facts and on this basis to predict and outline new development directions - applying the principles of sustainable construction and creating a new product that is sought after by consumers based on the use of new technologies and offering it to new target markets, defined on an effective market segmentation process. These decisions must be accompanied by clear assessments and forecasts of the reaction of competitors, customers, suppliers and government agencies that set and control product standards and general rules of the game.

Since the centralized structure presupposes the isolation of the top-level managers from the other lower-level units, the main means for achieving these goals is the construction of a multi-division structure. In this structure having modern organization of simultaneous teamwork, rather than consistent development and implementation of innovations, decentralization of collection rights, analysis of information and decisionmaking, flexible distribution of responsibilities and tasks, developed an effective system of incentives to achieve the desired results, etc. 
In order to reduce the contradictions between different subjects and opportunistic behavior, coordination is needed within the firm by building internal integrated systems of motivation and incentives, coordination of different goals of different groups and the firm as a whole and support the creation of corporate identity, culture and loyalty.

The process of learning, assimilation, dissemination and integration of external and internal knowledge is realized through the qualification of staff as a major factor for its stimulation and motivation in the long run. The goal of every company management in the first place is to create a well-coordinated team of professionals with experience, knowledge and skills. The development of special skills for work in different units, as well as the creation and management of working teams specializing in various functional activities, allows the successful solution of the tasks and the realization of the firm's goals - creating a sustainable construction firm.

It is especially important for the firm to create its own, unique sustainable business model, by analyzing many alternatives and informed assumptions about the behavior of competitors, customers, revenues and costs, and clear mechanism for adapting to the dynamic of external environment. The sustainable business model creates real preconditions for the realization of higher added value for the client, for the increase of the benefits in the society and ultimately for the realization of competitive advantages [7].

In the conditions of a dynamic environment, the managerial changes must be aimed at improving the connections and relations between the managers and all company units, the active participation of all subjects and units in the company "bottom-up". These changes ensure the adaptation and coordination of internal resources and competencies to external changes, through the development of intangible assets, which in turn have a reciprocal impact and develop tangible assets. The efforts of managers should be aimed at creating high customer loyalty and maintaining the company's reputation by analyzing the constant flow of information from the market, consumers, competitors, suppliers, for changes in demand and on this basis rapid customer feedback, data processing for the consumer evaluation of the company activity. The role of the leader is extremely important in making quality management decisions, motivation and creating incentives for employees in order to sustainably develop the firm.

The general conclusion of the managers is that the requirements for sustainable economic development and sustainable construction prove the need for a complete change in the behavior and policy of the construction firm - reorientation from short-term profit to long-term sustainable corporate development and stabilization of market positions, which allows building competitive advantages.

\section{CONCLUSIONS}

In today's dynamic conditions, the construction firm faces serious challenges related to the growing scarcity of resources used and the need to accelerate the process of implementing the principles of sustainable development. In the research the author aims to analyze the role of the market and the construction firm for sustainable development and on this basis to outline the necessary changes in the organization and management, which will enable the creation of a sustainable construction firm and competitive advantages.

The concept of sustainability is the new driving force for the firm and decisionmaking, in order to create, offer and realize additional economic, social and environmental value for the customer, stakeholders and society as a whole and build competitive advantages. Most researchers are adamant in their assessment that the construction market 
is inefficient because participants tend to work in the short term, find it difficult to perceive innovation and are limited in rational use of the accumulated knowledge and experience in their practice. This practically complicates the implementation of projects and sites that meet the requirements of sustainable construction and leads to fragmentation of responsibility.

The author formulates four hypotheses, each of which shows the relationship and influence of an integrated vertical management chain, of life cycle sustainable management of construction product, the need to build effective stakeholder relationships and the organizational changes on the creation of a sustainable construction firm. The defined hypotheses are tested empirically through a survey among managers and impose the conclusion that in practice the activity of a construction company can be defined as "sustainable" if it creates projects and objects on the following principles:

- All participants in the construction process - designers, architects, construction companies, administrative authorities, investors and clients participate from the earliest stages of the project. The creation of an integrated management chain creates and imposes higher standards and requirements for the creation of the final product that meets the principles of sustainability.

- The creation of the construction product integrates a wide range of design, construction, operational and maintenance practices, which ensures a healthier life, a better working atmosphere and reduces the negative impact on the environment. Thus, in practice, circular construction is implemented, which includes all stages of the product life cycle: raw materials, resources $\rightarrow$ product design $\rightarrow$ production $\rightarrow$ consumption, reuse $\rightarrow$ waste management and recycling $\rightarrow$ creation of new raw materials and resources for other industries.

- Buildings and infrastructure projects are more cost-effective, but provide higher economic, social and environmental efficiency to society and consumers. Construction projects and sites have a positive impact on the environment because they use recycled materials and systems with high durability and low maintenance costs throughout their life cycle.

- Sustainable construction is a long-term goal that requires a high degree of knowledge, competencies and interaction between all participants in the construction process. The construction firm is primarily an active economic entity that informs about innovations, guides consumers and changes their tastes and preferences.

- Sustainable construction requires a radical change in strategic behavior, organization and managing the activity of the construction firm at each stage of the construction process and throughout the life cycle of the construction product.

The main problem for each firm is the development and implementation of strategy and solutions related to change, improvement, refinement of its activities in order to create and offer a product that meets the principles of sustainable construction. Lack of sustainable strategy means corporate myopia, which leads to the loss of a specific image, market positions and the company becomes less and less attractive to its potential customers.

\section{REFERENCES}

[1] Rodriguez M., Ricart J., Sanchez P., (2002), Sustainable Development and the Sustainability of Competitive Advantage: A Dynamic and Sustainable View of the Firm, 
Creativity and Innovation Management, Vol.11, Iss.3, pp.135-146, https://doi.org/10.1111/1467-8691.00246

[2] Myers D., (2013), Construction Economics A new approach, Third Edition, Routledge, Taylor \& Francis Group, London and New York, pp. 284

[3] Life Cycle Management, A Business Guide to Sustainability, (2007), United Nations Environment Programme

[4] Robichaud L., Anantatmula V., (2011), Greening Project Management Practices for Sustainable Construction, Journal of Management in Engineering, Vol. 27, No.1

[5] Teece D., (2017), Towards a capability theory of (innovating) firms: implications for management and policy, Cambridge Journal of Economics, 41, 693-720, doi:10.1093/cje/bew063

[6] Ivanova V., (2020), Circular Economy: Barriers and Levers Promoting Transformation (Case Study Analysis), Management and Business Research Quarterly, (16), pp. 14-28, https://doi.org/10.32038/mbrq.2020.16.02

[7] Marichova A., (2019), Creating a Sustainable Business Model in the Construction Firm, Sciendo, Ovidius University Annals - Constantza, Series: Civil Engineering, Year 21, pp. $75-86$

Note:

Aneta Marichova - University of Architecture, Civil Engineering and Geodesy, 1, Hristo Smirnensky Boulevard, 1046-Sofia, Bulgaria (e-mail:aneta.marichova@abv.bg, marichova_fte @uacg.bg) 